\title{
Successful therapeutic management of canine Isosporosis in puppies
}

\author{
Nishiswapna Garanayak ${ }^{1}$ A. R. Gupta ${ }^{1}$ R. C. Patra ${ }^{1}$
}

Received: 2 August 2015/Accepted: 28 December 2015/Published online: 27 January 2016

(C) Indian Society for Parasitology 2016

\begin{abstract}
Four labrador male puppies were confirmed for the Isospora spp infection by direct smear and flotation method following complains of anorexia, haematemesis and haematochezia. The puppies were treated with trimethoprime and sulphamethoxazole @ $40 \mathrm{mg} / \mathrm{kg}$ body weight in combination with metronidazole @ $10 \mathrm{mg} / \mathrm{kg}$ body weight twice daily for 5 days which was supported with fluid therapy, aniemetics and plasma expanders. All the animals showed completed clinical recovery along with clearing of faecal oocyst.
\end{abstract}

Keywords Puppies - Isospora - Diarrhoea - Flotation method $\cdot$ Oocyst $\cdot$ Sulphamethoxazole and trimethoprime

\section{Introduction}

Diarrhoea among the puppies is a major health hazard encountered which can affect the normal development of the animal along with immunologically compromising it for various diseases and vaccination failure (Daugschies et al. 2000). Bacterial and viral diseases are the major culprits for diarrhoea among the puppies along with some parasitic origin. Attending proper protection by scheduled vaccination and deworming, the diarrhoea incidences of infectious origin can be reduced. Among the parasitic entities responsible for puppy diarrhoea coccidial organism Isospora spp. plays a vital role. Isospora associated diarrhoea has been reported prior (Baek et al. 1993) but the

Nishiswapna Garanayak

littlegaranayak@gmail.com

1 Orissa University of Agriculture and Technology, Bhubaneswar, Odisha, India clinical manifestations may be due to secondary bacterial and viral infections of the compromised gut environment (Lindsay et al. 1997; Lappin 2010; Altreuther et al. 2011).

The protozoan organism Isospora belongs to the kingdom-Protista, phylum-Apicomplexa, class-Sporozoea, Subclass-Coccidia, family-Eimeriidae and genus-Isospora (Levine 1977).

A large number of species diversity among the genus Isospora can be found along with a wide range of host organisms which includes human, primates, pig, canines and felines etc. (Levine 1988; Lindsay et al. 1997).

I. canis and $I$. ohioensis complex which includes 2 additional spp. I. burrowsi, I. neorivolta are the major miscreants for canine coccidiosis. Identification of the Isospora organisms is based on the dimensions and number of sporozoites and sporocysts present in the excreted oocyst from the host animal (Dubey 1978; Lindsay et al. 1997).

Young canines mostly get infected by ingestion of sporulated oocyst (Lindsay et al. 1997; Daugschies et al. 2000; Buehl et al. 2006; Dubey et al. 2009). Immune compromised puppies and stressed animals are under the enhanced risk of infection (Lappin 2010). I. canis establishes itself in the lamina propria of the posterior small intestine (Lepp and Todd 1974) resulting enteritis and mucosal damage due to schizogony and gamogony (Mitchell et al. 2007; Lappin 2010). The I. ohioensis complex infects the enterocytes in the lamina propria of small intestine, cecum, and colon of dogs resulting in villous atrophy, necrosis of apical enterocytes, and cryptitis (Dubey 1978; Dubey and Mahrt 1978; Trayser and Todd 1978).

The clinical implications include watery to haemorrhagic diarrhoea along with vomition, tenesmus and inappetance. Death due to excessive dehydration has been advocated by Daugschies et al. (2000) and Lappin (2010). 
Diagnosis of oocyst in the faecal matter by direct smear, Sheather sugar flotation method and sedimentation method with increasing order of sensitivity has been reported (Faust et al. 1961; Current 1990).

The present study deals with Isospora associated diarrhoea in four puppies and its successful management with sulphamethoxazole and trimethoprime combinations.

\section{Materials and methods}

Four labrador male puppies of $2-3$ month age were presented to the Teaching Veterinary clinical complex (TVCC) of College of Veterinary Science and AH, Bhubaneswar with history of anorexia, haematemesis, haematochezia for last 3 days with an average body temperature ranging from 101.8 to $102.2^{\circ} \mathrm{F}$. The puppies were vaccinated against distemper, hepatitis, parvo, parainfluenza, leptospira and corona virus following deworming with pyrantel pamoate@ $11 \mathrm{mg} / \mathrm{kg}$ body weight. Prior treatment regime of the puppies was done with Amikacin @ $10 \mathrm{mg} / \mathrm{kg}$ body weight without any clinical recovery. Faecal sample examination through direct smear method for presence of sporulated and non-sporulated oocyst of Isospora spp. was carried out which was later confirmed by flotation method (Soulsby 1986). Haematological findings of the infected animals showed haemoglobin $(\mathrm{Hb})$ level as $8.6 \pm 0.8 \mathrm{~g} / \mathrm{dl}$ and the differential count was within the normal range.

The puppies were administered with trimethoprime and sulphamethoxazole @ $40 \mathrm{mg} / \mathrm{kg}$ body weight in combination with metronidazole @ $10 \mathrm{mg} / \mathrm{kg}$ body weight twice daily for 5 days. As supportive therapy plasma expander @ $5 \mathrm{ml} / \mathrm{kg}$ body weight for 3 days along with Ringer's Lactate @ $30 \mathrm{ml} / \mathrm{kg}$ body weight twice daily for 5 days were given. Dextrose was administerd to the puppies to provide the energy@0.5 mg/kg body wt. Antiemetic metoclopramide@0.4 mg/kg body weight and haemocoagulase etamsylate@250 mg twice daily was given for 2 days.

\section{Result}

The direct faecal smear examination showed presence of Isospora oocyst which was confirmed by flotation method (Fig. 1) but Identification of the Isospora spp. was not confirmed. Basing on the internal anatomy of the oocyst it was concluded that both I. Canis and I. Ohioensis complex were present. History also confirmed the presence of mouse (Mus musculus) in the kennel premises which can act as the paratenic host of the infection as reported by Frenkel and Dubey (1972), Dubey (1977, 1978).

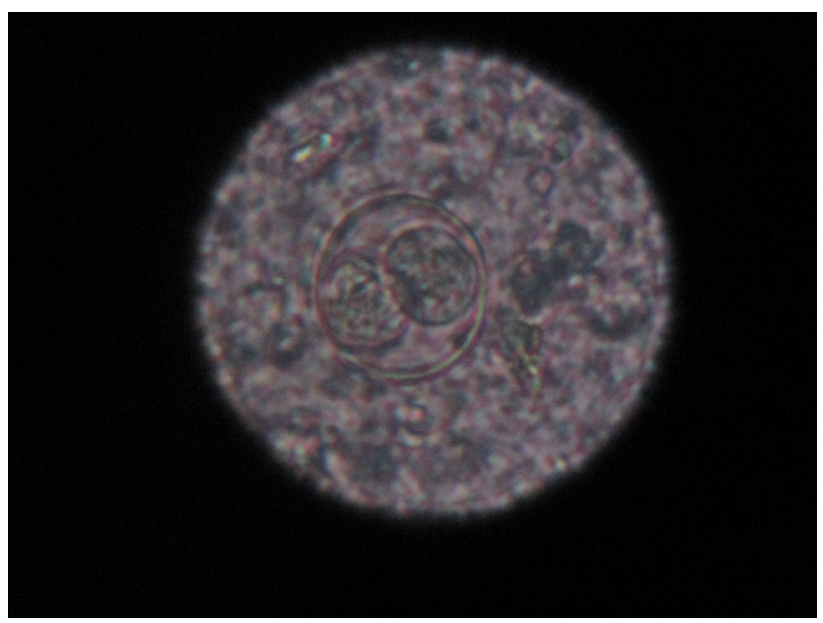

Fig. 1 Oocyst of Isospora spp. from faecal smear $(100 \times)$

The clinical recovery was observed from day one of treatment with absence of blood in vomitus and stool. The consistency of stool became normal after 2-6 days depending up to the clinical severity. However vomition tendency remained up to 8 days in 2 pups who started taking food with no clinical signs after 10 days. The faecal samples of all the puppies were free from oocysts as an indication of clinical recovery. The haemoglobin $(\mathrm{Hb})$ level fell back to normal range $(11 \pm 0.5 \mathrm{~g} / \mathrm{dl})$ within a span of 7 days.

\section{Discussion}

Isospora infection in puppies is the serious health concern due to its ability to spread through litter materials of kennel (Daugschies et al. 2000; Buehl et al. 2006). The infectivity of sporulated Isospora spp. oocysts can remain up to months along with the ability to resist the basic hygienic measures (Barutzki et al. 1981; Buehl et al. 2006). The infection leads to malabsorption in puppies rendering reduced vigour (Brandborg et al. 1970; Henry et al. 1974; Seah et al. 1975).

Identification of the Isospora spp. by structural morphology through flotation method and its superiority over the direct smear method has already been advocated for Isosporosis determination (Faust et al. 1961; Current 1990). However identification of the organism is not confirmatory based on oocyst structure which leads to the nomenclature of I. ohioensis-like or I. ohioensis complex (Dubey et al. 1978).

The recovery of the puppies by administration of trimethoprime and sulphamethoxazole along with supportive therapies and metronidazole resulted in complete clinical recovery with elimination of faecal oocyst. 
Similarly use of Sulfadimethoxine alone and in combination with ormetoprim has been proved effective in canines and felines (Wilkinson 1977; Dunbar and Foreyt 1985; Lindsay and Blagburn 1995). Administrations of emodepside plus toltrazuril suspension in combination with oral Amprolium have proven effectiveness against canine infection (Altreuther et al. 2011). Anti-giardial drugs like metronidazole, tinidazole, quinacrine, and furazolidone have very limited effect but metronidazole has been reported successful in some cases (Trier et al. 1974; Syrkis et al. 1975; Butler and deBoer 1981; Hallak et al. 1982; Forthal and Guest 1984; Weiss et al. 1988). The major aim of the treatment includes reduction of clinical signs along with reduction in faecal oocysts for interrupting the life cycle (Daugschies et al. 2000; Buehl et al. 2006). Supportive therapies like fluid administration are done depending on the severity of clinical signs which can enhance the recovery of the animals (Altreuther et al. 2011).

It was concluded that the canine Isosporosis can be clinically managed by use of trimethoprime and sulphamethoxazole along with supportive therapies and metronidazole. The major concern of the treatment should include elimination of faecal oocyst for interrupting life cycle of the disease.

\section{References}

Altreuther G, Gasda N, Schroeder I, Joachim A, Settje T, Schimmel A, Hutchens D, Krieger KJ (2011) Efficacy of emodepside plus toltrazuril suspension (Procox ${ }^{\circledR}$ oral suspension for dogs) against prepatent and patent infection with Isospora canis and Isospora ohioensis-complex in dogs. Parasitol Res 109:S9-S20

Baek BK, Kim CS, Kim JH, Han KS, Kim YG (1993) Studies on Isosporosis in dogs: isolation and sporulation of Isospora ohioensis. Korean J Parasitol 31(3):201-206

Barutzki D, Erber M, Boch J (1981) Möglichkeiten der Desinfektion bei Kokzidiose (Eimeria, Isospora, Toxoplasma, Sarcocystis). Berl Münch Tierärztl Wochenschr 94:451-454

Brandborg LL, Goldrerg SB, Breedenback WC (1970) Human coccidiosis-a possible cause of malabsorption. N Engl J Med 283:1306

Buehl IE, Prosl H, Mundt HC, Tichy AG, Joachim A (2006) Canine Isosporosis-epidemiology of field and experimental infections. J Vet Med B 53:482-487

Butler T, deBoer WGR (1981) Isospora belli infection in Australia. Pathology 13:593-595

Current WL (1990) Techniques and laboratory maintenance of Cryptosporidium. In: Dubey JP, Speer CA, Fayer R (eds) Cryptosporidiosis of man and animals. CRC Press Inc, Boca Raton, pp 31-49

Daugschies A, Mundt HC, Letkova V (2000) Toltrazuril treatment of cystisosporosis in dogs under experimental and field conditions. Parasitol Res 86:797-799

Dubey JP (1977) Toxoplasma, Hammondia, Besnoitia, Sarcocystis, and other tissue cyst-forming coccidia of man and animals. In:
Krier JP (ed) Parasitic protozoa, vol 3. Academic Press, New York, pp 101-237

Dubey JP (1978) Life cycle of Isospora ohioensis in dogs. Parasitology $77: 1-11$

Dubey JP, Mahrt JL (1978) Isospora neorivolta sp. n. from the domestic dog. J Parasitol 64:1067-1073

Dubey JP, Weisbrode SE, Rogers WA (1978) Canine coccidiosis attributed to an Isospora ohioensis-like organism: a case report. J Am Vet Med Assoc 173:185-191

Dubey JP, Lindsay DS, Lappin MR (2009) Toxoplasmosis and other intestinal coccidial infections in cats and dogs. Vet Clin Small Anim 39:1009-1034

Dunbar MR, Foreyt WJ (1985) Prevention of coccidiosis in domestic dogs and captive coyotes (Canis latrans) with sulfadimethoxine-ormetoprim combination. Am J Vet Res 46:1899-1902

Faust EC, Giraldo LE, Giraldo G, Bonfante R (1961) Human coccidiosis in the western hemisphere. Am J Trop Med Hyg $10: 343-350$

Forthal D, Guest SS (1984) Isospora belli enteritis in three homosexual men. Am J Trop Med Hyg 33:1060-1064

Frenkel JK, Dubey JP (1972) Rodents as vectors for the feline coccidia, Isospora felis and Isospora rivolta. J Infect Dis 125:69-72

Hallak A, Yust I, Ratan Y, Adar U (1982) Malabsorption syndrome, coccidiosis, combined immune deficiency, and fulminant lymphoproliferative disease. Arch Intern Med 142:196-197

Henry K, Bian RG, Doe WF (1974) Intestinal coccidiosis in a patient with alpha-chain disease. Br Med J 1:542

Lappin MR (2010) Update on the diagnosis and management of Isospora spp. infections in dogs and cats. Top Companion Anim Med 25:133-135

Lepp DL, Todd KS (1974) Life cycle of Isospora canis Nemeseri, 1959 in the dog. J Protozool 21:199-206

Levine ND (1977) Nomenclature of Sarcocystis in Ox and sheep and fecal coccidian of the dog and cat. J Parasitol 63(1):36-51

Levine ND (1988) The protozoan phylum Apicomplexa, vol 1. CRC Press Inc, Boca Raton

Lindsay DS, Blagburn BL (1995) Practical treatment and control of infections caused by canine gastrointestinal parasites. Vet Med 89:441-455

Lindsay DS, Dubey JP, Blagburn BL (1997) Biology of Isospora spp. from humans, nonhuman primates, and domestic animals. Clin Microbiol Rev 10(1):19-34

Mitchell SM, Zajac AM, Charles S, Duncan RB, Lindsay DS (2007) Cystoisospora canis Nemeséri, 1959 (syn. Isospora canis), infections in dogs: clinical signs, pathogenesis, and reproducible clinical disease in Beagle dogs fed oocysts. J Parasitol 93:345-352

Seah SKK, Hucal G, Law C (1975) Dogs and intestinal parasites: a public health problem. CMA J 112:1191-1194

Soulsby EJL (1986) Helminths, Arthropods and Protozoa of domesticated animals, 7th edn. ELBS publication, Lea and Febiger, University of Michigan, pp 1-809

Syrkis I, Fried M, Elian I, Pietrushka D, Lengy J (1975) A case of severe human coccidiosis in Israel. Isr J Med Sci 11:373-377

Trayser CV, Todd KS (1978) Life cycle of Isospora burrowsi n sp (Protozoa: Eimeriidae) from the dog Canis familiaris. Am J Vet Res 39:95-98

Trier JS, Moxey PC, Schimmel EM, Robles E (1974) Chronic intestinal coccidiosis in man: intestinal morphology and response to treatment. Gastroenterology 66:923-935

Weiss LM, Perlman DC, Sherman J, Tanowitz H, Wittner M (1988) Isospora belli infection: treatment with pyrimethamine. Ann Intern Med 109:474-475

Wilkinson GT (1977) Coccidial infection in a cat colony. Vet Rec 100:156-157 